\title{
$\widehat{A}$ Madridge \\ madridge Journal of Dentistry and Oral Surgery
}

\author{
Interconnecting Scientific World
}

Research Article

Open Access

\section{Part II: Dentinogenic Effect of Magnesium Oxide on Expression of Extracellular Matrix Proteins in Normal Human Dental Pulp Cells: An In Vitro Study}

\author{
Rania M Salem ${ }^{1,2 \star}$, Chang Zhang ${ }^{1}$ and Laisheng Chou ${ }^{1}$ \\ ${ }^{\prime}$ Department of Restorative Sciences \& Biomaterials, Goldman School of Dental Medicine, Boston University, Boston, MA 02118, United States \\ ${ }^{2}$ Department of Endodontics, Goldman School of Dental Medicine, Boston University, Boston, MA 02118, United States
}

\section{Article Info \\ *Corresponding author: \\ Rania M Salem \\ Department of Restorative Sciences \& Endodontics \\ Goldman School of Dental Medicine \\ Boston University \\ USA \\ Tel: +3474093109 \\ E-mail: rmsalem@bu.edu}

Received: December 14, 2021

Accepted: December 21, 2021

Published: December 31, 2021

Citation: Salem RM, Zhang C, Chou L. Part II: Dentinogenic Effect of Magnesium Oxide on Expression of Extracellular Matrix Proteins in Normal Human Dental Pulp Cells: An In Vitro Study. Madridge J Dent Oral Surg. 2021; 6(1): 116-126.

doi: $10.18689 / \mathrm{mjdl}-1000125$

Copyright: (c) 2021 The Author(s). This work is licensed under a Creative Commons Attribution 4.0 International License, which permits unrestricted use, distribution, and reproduction in any medium, provided the original work is properly cited.

Published by Madridge Publishers

\begin{abstract}
Magnesium-based biomaterials provide an innovative therapeutic potential to substantially enhance regeneration of dental tissues. However, to date, magnesium oxide (MgO) and its effect on odontogenic differentiation of human dental pulp cells (HDPCs) has not been investigated and the underlying regulatory mechanisms of $\mathrm{MgO}$ remain undefined. This study was designed to evaluate the stimulatory effect of different concentrations of $\mathrm{MgO}$ on odontogenic differentiation with the expression of extracellular matrix-related proteins (dentin sialoprotein (DSP), dentin matrix protein 1 (DMP-1), dentin sialophosphoprotein (DSPP), and collagen-Type I (COL-I). An aqueous $\mathrm{MgO}$ suspension was prepared. HDPCs were cultured with $0.5 \mathrm{mM}, 1 \mathrm{mM}, 2 \mathrm{mM}, 4 \mathrm{mM}$, $8 \mathrm{mM}$ concentrations of supplemental $\mathrm{MgO}, 0 \mathrm{mM}$ as the negative control group, lignin sulfonic acid sodium salt and xanthan gum as the vehicle control groups. Odontoblastic differentiation was assessed by evaluating expression of odontogenic-related proteins: DSP, DMP-1, DSPP, and COL-I. Statistical analysis was done using Multi-Way Analysis of Variance (MANOVA) with Wilks' lambda test. $0.5 \mathrm{mM} \mathrm{MgO}$ elicited the highest stimulatory effect on odontogenic differentiation with significant upregulation of expression of odontogenic-related proteins (DSP, DMP-1, DSPP, COL-I) compared to the negative control $(P<0.0001)$. This is the first report revealing that $\mathrm{MgO}$-enriched micro-environment promoted odontogenic differentiation in HDPCs. Magnesium oxide containing biomaterials could be used as a new strategy for dental pulp regeneration in regenerative endodontics.
\end{abstract}

Keywords: Magnesium oxide; Odontogenic differentiation; Extracellular matrix proteins; Dentinogenesis

\section{Introduction}

Dental caries, one of the most common oral diseases globally, is the main reason for dental hard tissues destruction and pulp exposure [1-3]. In this situation, direct pulp capping is the only treatment option that enables preservation of pulp vitality and activation of dentin regeneration. Pulp capping involves the placement of a protective dressing over the exposed pulp area to stimulate tertiary dentin formation. Calcium hydroxide $\left[\mathrm{Ca}(\mathrm{OH})_{2}\right]$ has long been considered the gold standard of pulp capping materials; more recently, mineral trioxide aggregate (MTA) has found wide clinical use for this application $[4,5,6]$. However, neither material was originally developed to induce cellular repair of the dentin-pulp complex, such treatment should be based on the key biological events associated with tissue repair. The understanding of tertiary 
dentinogenesis, as well as the ability to modify this process within the clinical setting, remain incomplete. This constrains the development of optimal pulp capping materials that are compatible with the biological events occurring during dentin-pulp repair and regeneration [7-9]. Therefore, a novel approach understanding the molecular and cellular bases for pulp regeneration and dental tissue repair for successful clinical treatment of pulp injuries is urgently needed.

Regenerative endodontic therapy has been assayed with multiple mesenchymal stem cells (MSCs), growth factors, and biological materials [10-12]. Magnesium-containing scaffolds are considered to be potential biomaterials for such treatment, with the properties of releasing $\mathrm{Mg}^{2+}$ to enhance the dentin regeneration in MSCs [13]. $\mathrm{Mg}^{2+}$ acts as an intracellular second messenger connecting cell-surface receptor induction and cytosolic effectors [14]. $\mathrm{Mg}^{2+}$ is the fourth most abundant cation in the human body and is critical for ATP- dependent phosphorylation of DNA, RNA, and enzymes, and the average $\mathrm{Mg}^{2+}$ concentration in dentin is about 1\% (wt/wt) [15-17]. $\mathrm{Mg}^{2+}$ plays pivotal roles in regulating osteogenesis, which exhibits concentration-dependent behaviors. Numerous reports have demonstrated that $\mathrm{MgO}$-doped bioceramics, either used directly or as fillers for polymeric biomaterials, are able to enhance osteogenic differentiation and stimulate osteogenesis [18-21]. MgO containing materials has also been reported to enhance expression of collagen I, ALP, and osteocalcin, improved ALP activity in human fetal osteoblastic (hFOB) cells and human bone-derived cells [18-25].

In our previous study, it was reported that $\mathrm{MgO}$ has proven biocompatibility, upregulated HDPCs attachment, enhanced proliferation, and induced upregulation of ALP activity with involvement in dentin mineralization [26]. These findings open opportunities to use $\mathrm{MgO}$ in vital pulp therapies as a promising choice for dentin repair $[27,28]$. However, the underlying mechanisms of $\mathrm{MgO}$ effects on odontogenic differentiation in HDPCs remain undefined. This is the first research further investigating the effects of $\mathrm{MgO}$ on odontoblastic maturation and differentiation in terms of dentin sialoprotein (DSP), dentin matrix protein -1 (DMP-1), dentin sialophosphoprotein (DSPP) and collagen-Type I (COL-I) in HDPCs in vitro.

The hypothesis of the present study was that $\mathrm{MgO}$ will induce the odontoblastic differentiation of HDPCs. Therefore, the main target of the present contribution was to determine the biological effect of $\mathrm{MgO}$ in terms of 1 - To evaluate the effect of different concentrations of $\mathrm{MgO}$ in terms of the odontogenic differentiation of HDPCs in vitro 2- To assess the expression levels of extracellular matrix-related proteins of dentin sialoprotein (DSP), dentin matrix protein-1 (DMP-1), dentin sialophosphoprotein (DSPP) and collagen-Type I (COL-I) mediating the odontogenic activity and differentiation potential of HDPCs into a mineralizing lineage. In this context, clarifying the potential role of $\mathrm{MgO}$-enriched microenvironment to support the development of a new generation of biologically-based pulp capping materials and their clinical benefits for regenerative endodontic treatment.

\section{Materials and Methods}

\subsection{Preparation of concentrated magnesium oxide suspension}

Magnesium oxide (Mag Chem 10, Martin Marietta Magnesia Specialties, MD, USA) powder milled size ranging from 44 to 297 micron was used for an aqueous magnesium oxide suspension with water, lignin sulfonic acid sodium salt (anti-hydration agent) and xanthan gum (suspension aid), resulting in a highly stable concentrated suspension (according to the patent developed by [29]. Five stock solutions were prepared at concentrations of $5 \mathrm{mM}, 10 \mathrm{mM}$, $20 \mathrm{mM}, 40 \mathrm{mM}$ and $80 \mathrm{mM}$ respectively.

\subsection{Lignosulfonic acid sodium salt and xanthan gum solvent preparation}

Lignosulfonic acid sodium salt and xanthan gum (Sigma Aldrich, MA, USA) dissolved in deionized water were subsequently filtered under sterile condition in the biological hood, kept in a labeled container and stored at room temperature, utilized as vehicle controls to be compared to the negative control.

\subsection{Human dental pulp cell (HDPC) culture}

Under an Institutional Review Boards (IRB) approval $\mathrm{H}-33173$, dental pulp explants were isolated from freshly extracted third molars provided from 15 to 18-year-old female patients undergoing routine third molar extraction at the oral surgery clinic at Boston University. The HDPCs were cultured according to the protocol published by [30]. Teeth were split open with a \#7 chandler bi-bevel bone chisel and hammer. The exposed dental pulp explants were transferred immediately into a $25 \mathrm{~cm}^{2}$ culture flask (Thermo Fisher Scientific, Cambridge, MA, USA), containing Basal Medium Eagle's (BME) culture medium supplemented with $10 \%$ fetal bovine serum (R\&D Systems, MN, USA), $100 \mathrm{U} / \mathrm{mL}$ of Penicillin (Gibco, MA, USA), $100 \mathrm{mg} / \mathrm{mL}$ streptomycin (Gibco, MA, USA), and $0.25 \mathrm{ug} / \mathrm{mL}$ amphotericin-B (Gibco, MA, USA). The HDPCs were incubated in humidified atmosphere at $37^{\circ} \mathrm{C}$, with $5 \%$ $\mathrm{CO} 2$ and cultured up to the second passage. The culture medium was replaced every 3 days until the cells reached $80 \%$ confluence. The cells were detached after reaching $80 \%$ confluence using $0.05 \%$ Trypsin-EDTA (Thermo Fisher Scientific, MA, USA), centrifuged (TJ-6 Beckman Centrifuge) for $5 \mathrm{~min}$ at $1000 \mathrm{rpm}$, counted using hemocytometer and then were utilized for the experiments.

\subsection{Odontogenic differentiation induction of HDPCs}

Three thousand normal HDPC cells were seeded in 24-well plates containing $1 \mathrm{~mL}$ of growth medium supplemented with various $\mathrm{MgO}$ concentrations $0.5 \mathrm{mM}, 1 \mathrm{mM}, 2 \mathrm{mM}, 4 \mathrm{mM}$ $8 \mathrm{mM}$ and $0 \mathrm{mM}$ as a control group, lignin sulfonic acid sodium salt and xanthan gum as vehicle controls. Each condition was repeated in five replicas. The culture plates were incubated under $37^{\circ} \mathrm{C}, 5 \% \mathrm{CO} 2$ and growth media were changed every 3 days. Cell differentiation was monitored at the predetermined time points: 7 days, 10 days, and 14 days. Growth media were replaced with pre-inductive dentinogenic media at the following time intervals: 4, 7, and 11 days. 
Dentinogenic media consisted of the following: 10\% charcoal stripped fetal bovine serum (FBS) (Life Technologies, MA, USA), $100 \mathrm{U} / \mathrm{ml}$ Penicillin (Gibco, MA, USA), $100 \mu \mathrm{g} / \mathrm{mL}$ streptomycin (Gibco, MA, USA), 10-8 M Menadione (Sigma Aldrich, MA, USA), $10 \mathrm{mM} \beta$-Glycerophosphate (Sigma Aldrich, MA, USA), $0.05 \mathrm{mg} / \mathrm{mL}$ L-ascorbic acid (Sigma Aldrich, MA, USA), 2 mM L-glutamine (Gibco, MA, USA). The next day, cells were cultured in pre-inductive dentinogenic media with the addition of $10 \mathrm{nM}$ Vitamin $\mathrm{D}_{3}(172 \mathrm{~g} / \mathrm{mol})$ (Sigma Aldrich, MA, USA). Cell numbers at each time points under different concentrations of supplemental $\mathrm{MgO}$ and control groups were determined by $0.2 \%$ crystal violet staining (SigmaAldrich, MA, USA). The density of stained cells was measured by the spectrophotometer (TECAN, Infinite 200 Pro) at wavelength $590 \mathrm{~nm}$. Characterization of dentinogenic phenotype of the cells was then confirmed by expression of dentinogenic markers induced by vitamin $D_{3}$ stimulation. Supernatant fluid was collected on 7, 10, and 14 days. DSP, 1 DMP-1, DSPP and COL-I were measured in the collected supernatant. The remaining fixed cells on the culture plates were used to perform the differentiation assay. At each predetermined time point, $0.2 \%$ crystal violate dye was used to stain the attached cells in the 24-well plates. Absorbance of crystal violet was measured using the spectrophotometer at $590 \mathrm{~nm}$ wavelength.

\subsection{Assessment of HDPCs dentin sialoprotein (DSP) expression}

Supernatant samples were tested at 7, 10, and 14 days. DSP Xpress Bio ${ }^{\mathrm{TM}}$ ELISA Kit (Frederick, MD, USA) was used to measure DSP expression according to the manufacturer's instructions. $100 \mu \mathrm{L}$ ( $2 \mathrm{x}$ diluted) culture supernatants were incubated with $100 \mu \mathrm{L}$ of biotin conjugated detection antibody in a 96 well black plate with clear bottom (Thermo Scientific, Cambridge, MA, USA). The plates were incubated for 60 minutes at $37^{\circ} \mathrm{C}$. Then, $100 \mu \mathrm{L}$ horse radish peroxidase (HRPStreptavidin) conjugate was added into each well and incubated for 30 minutes. The culture plates were decanted and washed four times. $90 \mu \mathrm{L}$ TMB substrate was then added into each well. TMB was catalyzed by HRP Streptavid in producing a light blue color. The mixture was then incubated and protected from light for $10-20$ minutes at $37^{\circ} \mathrm{C}$. Finally, the reaction was terminated by adding $50 \mu \mathrm{L}$ stop solution to each well, followed by gentle shaking of the plate. The intensity of the solution color was then measured spectrophotometrically at $450 \mathrm{~nm}$ in a micro-plate reader (TECAN, Infinite 1000 Pro). Five measurements were performed for averaging. DSP expression was calculated by a standard curve and normalized to DSP expression on a per million cell base formula.

\subsection{Assessment of HDPCs dentin matrix protein (DMP-1) expression}

Supernatant samples at days 7, 10, and 14 were tested using DMP -1Xpress Bio ${ }^{\mathrm{TM}}$ (Frederick, MD, USA) ELISA Kit (Human) following the manufacturer's instructions. This kit was based on sandwich enzyme-linked immune-sorbent assay technology utilizing anti- DMP1 antibody and the biotin anti- DMP1 conjugate. $100 \mu \mathrm{L}$ ( $2 x$ diluted) supernatant samples were added to all 96 microstrip-well plates for 90 min with shaking on a horizontal orbital microplate shaker ( 0.12 " orbit) set at $500 \pm 50 \mathrm{rpm}$. The culture plates were decanted and washed two times. The wells were then incubated with $100 \mu \mathrm{L}$ of biotin conjugated detection antibody. The plate was then covered with a plate sealer and incubated for 60 minutes at $37^{\circ} \mathrm{C}$. After decanting and washing as described earlier, 100 $\mu \mathrm{L}$ HRP-Streptavidin conjugate was added into each well and incubated for 30 minutes. TMB was catalyzed by HRP producing a light blue color. The reaction was terminated by adding $50 \mu \mathrm{L}$ stop solution, resulting in a yellow color. The intensity of the solution color was then measured spectrophotometrically at $450 \mathrm{~nm}$ in a micro-plate reader. Five measurements were performed for averaging. DMP-1 concentration was calculated by a standard curve and normalized to DMP-1 expression measured per million of cells.

\subsection{Assessment of HDPCs dentin sialophosphoprotein (DSPP) expression}

DSPP Cusabio ${ }^{\mathrm{TM}}$ (Houston, TX, USA) ELISA Kit (Human) was used to evaluate the expression levels of secreted DSPP. This assay employs the quantitative sandwich enzyme immunoassay technique. In a 96-well microplate, supernatants were collected at days 7,10 , and 14, and the assay was carried out following the manufacturer's recommendations. $100 \mathrm{u} \mathrm{L}$ of standards, test samples and controls (blanks) were added into each well. Plates were covered with adhesive strips and incubated for 2 hours at $37^{\circ} \mathrm{C}$. $100 \mu \mathrm{L}(1 \mathrm{x}$ ) of biotin- conjugated antibody was added to the appropriate wells. Plates were then incubated for 60 minutes at $37^{\circ} \mathrm{C}$. The culture plates were decanted and washed two times. Thereafter, $100 \mu \mathrm{L}$ of avidin conjugated Horseradish Peroxidase (HRP-avidin) (1x) was added into each well. Incubation of the plates was performed for 60 minutes. After decanting and washing as described earlier, $90 \mu \mathrm{L}$ TMB substrate was added for 15-30 min at $37^{\circ} \mathrm{C}$. $20 \mu \mathrm{L}$ stop solution was then added, turning the solution color from blue to yellow. The microplate reader (TECAN, Infinite 1000 Pro) was set at a wavelength of $450 \mathrm{~nm}$ to identify the intensity of color (O.D) versus the respective DSPP concentration. Five measurements were performed. DSPP expression was calculated by a standard curve to obtain the concentration measured per million of cells.

\subsection{Assessment of HDPCs collagen-type I (COL-I) expression}

To assess the expression level of secreted COL-I, Xpress Bio $^{\mathrm{TM}}$ (Frederick, MD, USA) ELISA Kit (Human) was used based on sandwich enzyme-linked immune-sorbent assay technology. Capture antibody and a biotin conjugate detection antibody were utilized. Following the manufacturer's instructions, supernatants at days 7, 10, and 14 were diluted (2x). $100 \mu \mathrm{L}$ of the diluted test samples, standards and controls were added into a 96 well black plate with clear bottom (Thermo Scientific, Cambridge, MA, USA). Test samples were incubated at $37^{\circ} \mathrm{C}$ for 90 minutes. $100 \mu \mathrm{L}$ of the biotin conjugated detection antibody was added to the wells. The plates were covered and incubated for 60 minutes at $37^{\circ} \mathrm{C}$. The plates were decanted and washed three times. Afterwards, 
$100 \mu \mathrm{L}$ HRP-Streptavidin was added into each well and incubated for 30 minutes at $37^{\circ} \mathrm{C}$. The plates were decanted and washed five times. $90 \mu \mathrm{L}$ TMB substrate was placed into each well and incubated in the dark for 10-20 minutes. The reaction was terminated by adding $50 \mu \mathrm{L}$ stop solution resulting in a yellow color immediately. Following the completion of the assay, the intensity of the solution color was measured spectrophotometrically at $450 \mathrm{~nm}$ in a microplate reader (TECAN, Infinite 1000 Pro). Five measurements were performed. COL-I concentration was calculated by a standard curve and normalized to COL-I expression to on a per million cell base formula.

\subsection{Statistical analysis}

Descriptive statistics is presented in Tables 1-10. The means and standard deviations (SD) of HDPCs differentiation data and the levels of dentinogenic differentiation markers (DSP, DMP-1, DSPP, and COL-I) were calculated at 7, 10, and 14 days. The data were normalized on a per million cells basis at the same time points. Statistical analysis was performed using software JMP Pro 13 (ver. 13.1.0). Multi-Way Analysis of Variance (Multi-Way ANOVA) with Wilks' lambda test was used for statistical analysis between the groups. Differences at $P \leq 0.05$ were considered statistically significant.

\section{Results}

\subsection{Effect of MgO on numbers of HDPCs at various concentrations (after addition of preinductive- dentinogenic media)}

Initially, HDPCs at day 7 grew to a statistically significant higher number with the $0.5 \mathrm{mM}$ supplemental $\mathrm{MgO}$ concentration compared to the negative control and the vehicle control groups $(P<0.001)$ (Figure 1) (Table 1). However, the supplemental $\mathrm{MgO}$ concentration groups higher than 0.5 $\mathrm{mM}$ did not grow to high levels as the $0.5 \mathrm{mM}$ group, also showed significantly lower levels compared to the negative and vehicle controls $(P<0.001)$. Wilks' Lambda interaction $\mathrm{P}$-value for supplemental $\mathrm{MgO}$ concentrations demonstrated a statistically significant value at this time point $(p<0.001)$. Meanwhile, at day 10 , the $0.5 \mathrm{mM}$ supplemental $\mathrm{MgO}$ concentration group displayed even higher significant results than the control groups $(P<0.001)$. The supplemental $\mathrm{MgO}$ concentration groups higher than $0.5 \mathrm{mM}$ behaved similarly to the day 7 time point $(P<0.001)$. Wilks' Lambda interaction $P$-value for supplemental $\mathrm{MgO}$ concentrations pointed out a statistically significant value $(p<0.001)$ (Table 2$)$. At day 14 , the $0.5 \mathrm{mM}$ supplemental concentations still showing an enhanced differentiation $(P<0.001)$. Meanwhile, the vehicle control groups showed a gradual increase throughout the experiment, reaching a statistically significant value $(P<0.001)$. Supplemental $\mathrm{MgO}$ concentration groups higher than 0.5 $\mathrm{mM}$, showed significantly decreased growth compared to the negative control and the vehicle control groups respectively $(p<0.001)$. Wilks' Lambda interaction P-value for supplemental $\mathrm{MgO}$ concentrations showed a statistically significant value $(p<0.001)$.

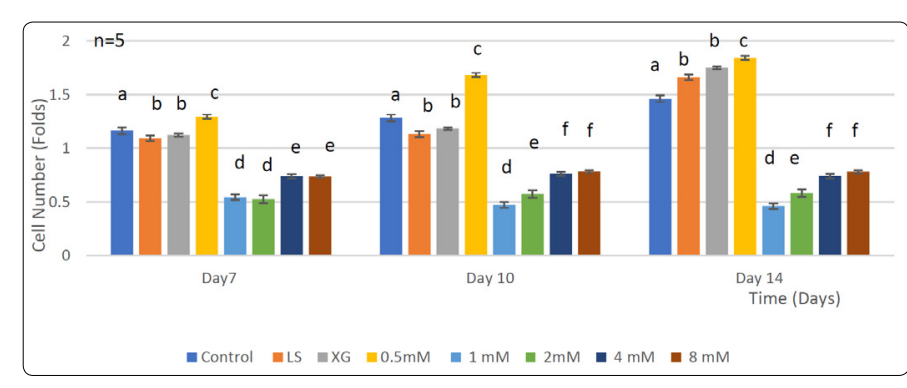

Figure 1. Bar graph showing numbers of normal human dental pulp cells in media with tested supplemental magnesium oxide ( $\mathrm{MgO})$ concentrations: $0.5 \mathrm{mM}, 1 \mathrm{mM}, 2 \mathrm{mM}, 4 \mathrm{mM}, 8 \mathrm{mM}$ and $0 \mathrm{mM}$ as the control group, lignin sulfonic acid sodium salt and xanthan gum vehicle controls groups after addition of pre-inductive odontogenic media for time periods of 7,10 and 14 days. Different letters indicate a significant difference between groups $(P<0.001)$ compared to the control in each condition at the specified time point. Error bars indicate the standard deviations of five replicates

Table 1. P-values of cell differentiation within groups for Multi-Way ANOVA (MANOVA) of magnesium oxide (MgO) concentrations

\begin{tabular}{|l|l|l|l|l|l|}
\hline Test & Value & Exact F & Num DF & Den DF & Prob $>$ F \\
\hline F Test & 6.8676877 & 32.0492 & 6 & 28 & $<.001^{*}$ \\
\hline
\end{tabular}

Table 2. Wilks' Lambda Interaction P-Values for Magnesium Oxide Cell Differentiation at Different Time Intervals $(P<0.001)$

\begin{tabular}{|l|l|l|l|l|l|}
\hline Test & Value & Approx. F & Num DF & Den DF & Prob $>$ F \\
\hline Wilks' Lambda & 0.1962769 & 5.6573 & 12 & 54 & $<.001^{*}$ \\
\hline
\end{tabular}

\subsection{Effect of $\mathrm{MgO}$ on dentin sialoprotein (DSP) expression of HDPCs at various concentrations}

DSP expression of HDPCs was analyzed at 7, 10, and 14 days. At day 7 , the $0.5 \mathrm{mM}$ supplemental $\mathrm{MgO}$ concentration group showed an increase in DSP expression compared to the negative control and the other groups with a statistically significant difference $(P<0.001)$ (Figure 2) (Table 3). Wilks' Lambda interaction $\mathrm{P}$-value for $\mathrm{MgO}$ concentrations and their DSP expression demonstrated a statistically significant value $(p<0.001)$ (Table 4). At day 10, as for the $0.5 \mathrm{mM}$ supplemented $\mathrm{MgO}$ concentration group, DSP reached an even higher value. Wilks' Lambda interaction P-value for MgO concentrations and DSP expression showed a significant value $(p<0.001)$. Additionally, at day 14 the highest effect on DSP expression was noted by the $0.5 \mathrm{mM} \mathrm{MgO}$ concentration group $(P<0.001)$. Data showed that the vehicle control groups showed an increase in DSP expression reaching the highest value by 14 days $(P<0.001)$. Wilks' Lambda interaction $\mathrm{P}$ - value for $\mathrm{MgO}$ concentrations and DSP expression showed a marked significant value $(p<0.001)$. The trend of the results during the whole assay as seen in Figure 2 showed that the $0.5 \mathrm{mM} \mathrm{MgO}$ concentration upregulated DSP expression significantly at all the tested time intervals of 7,10 , and 14 days. 


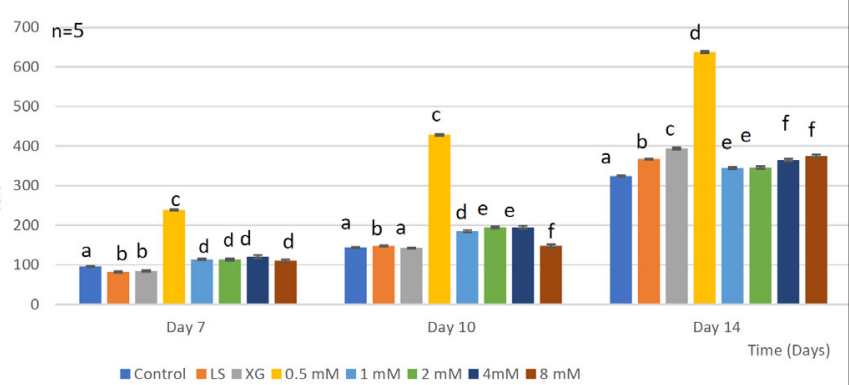

Figure 2. Bar graph showing dentin sialoprotein (DSP) expression of normal human pulp cells in media supplemented with magnesium oxide (Mg O) concentrations $0.5 \mathrm{mM}, 1 \mathrm{mM}, 2 \mathrm{mM}, 4 \mathrm{mM}, 8 \mathrm{mM}$ and $0 \mathrm{mM}$ as control group, lignin sulfonic acid sodium salt and xanthan gum as vehicle controls for time periods of 7, 10, and 14 days. Dentin sialoprotein (DSP) expression in supernatants was normalized per million cells at each time interval. The control cells were treated without supplemental magnesium oxide. Different letters indicate a significant difference between groups $(P<0.001)$ compared to the control in each condition at the specified time

point. Error bars indicate the standard deviations of five replicates

Table 3. P-values within Groups for Multi-way ANOVA (MANOVA) for Dentin Sialoprotein (DSP) Expression of Magnesium Oxide (MgO) Concentrations $(<0.001)$

\begin{tabular}{|l|l|l|l|l|l|}
\hline Test & Value & Exact F & Num DF & Den DF & Prob $>$ F \\
\hline F Test & 59.697413 & 1074.5534 & 1 & 18 & $<.001^{\star}$ \\
\hline
\end{tabular}

Table 4. Wilks' Lambda for the interaction P-values of Magnesium Oxide Dentin Sialoprotein (DSP) Expression at Different Time Intervals $(P<0.001)$

\begin{tabular}{|l|l|l|l|l|l|}
\hline Test & Value & Approx. F & Num DF & Den DF & Prob $>$ F \\
\hline Wilks' Lambda & 0.0131025 & 31.8044 & 18 & 74 & $<.001^{*}$ \\
\hline
\end{tabular}

\subsection{Effect of MgO on dentin matrix protein-1 (DMP-1) expression of HDPCs at various concentrations}

Analysis of DMP-1 expression of HDPCs demonstrated a significant increase in the $0.5 \mathrm{mM}$ supplemental $\mathrm{MgO}$ concentration group $(P<0.001)$ compared to all other experimental groups, the negative and vehicle control groups $(P<0.001)$ at day 7 (Figure 3) (Table 5). In the $0.5 \mathrm{mM} \mathrm{MgO}$ concentration group, there were also significant timedependent increase of DMP-1 expression $(P<0.001)$ from 7 to 14 days. Wilks' Lambda interaction $P$ - value for magnesium oxide concentrations and their DMP-1 expression demonstrated a statistically significant value $(P<0.001)$ (Table 6). In comparison to the $0.5 \mathrm{mM} \mathrm{MgO}$ concentration group, other higher $\mathrm{MgO}$ concentration groups showed significantly lower DMP-1 expression $(P<0.001)$. MgO concentration groups higher than $0.5 \mathrm{mM}$ showed slightly lower DMP-1 expression at days 10 and 14 comparable to the negative control and vehicle control. Comparing different time intervals for the whole assay clearly demonstrated a noticeable effect evident by the $0.5 \mathrm{mM}$ supplemental $\mathrm{MgO}$ concentration on DMP-1 expression of HDPCs.

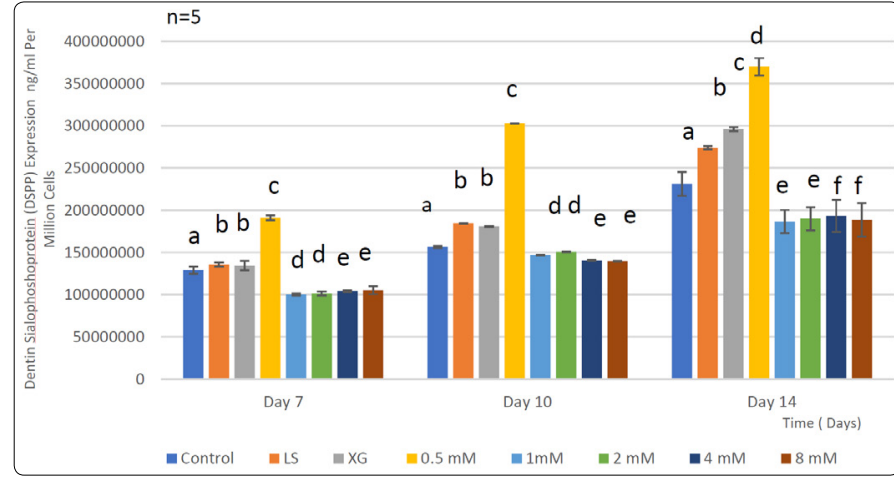

Figure 3. Bar graph showing dentin matrix protein 1 (DMP-1) expression of normal human pulp cells in media supplemented with magnesium oxide (MgO) concentrations $0.5 \mathrm{mM}, 1 \mathrm{mM}, 2 \mathrm{mM}, 4 \mathrm{mM}, 8 \mathrm{mM}$ and $0 \mathrm{mM}$ as control group, lignin sulfonic acid sodium salt and xanthan gum as vehicle controls for time periods of 7,10, and 14 days. Dentin matrix protein-1

(DMP-1) expression in supernatants was normalized per million cells at each time interval. The control cells were treated without supplemental magnesium oxide. Different letters indicate a significant difference between groups $(P<0.001)$ compared to the control in each condition at the specified time point. Error bars indicate the standard deviations of five replicates

Table 5. P-values within Groups for Multi-way ANOVA (MANOVA) for Dentin Matrix Protein 1(DMP-1) Expression of Magnesium Oxide (MgO) Concentrations $(<0.001)$

\begin{tabular}{|l|l|l|l|l|l|}
\hline Test & Value & Exact F & Num DF & Den DF & Prob $>$ F \\
\hline F Test & 7.0051793 & 161.1191 & 1 & 23 & $<.001^{\star}$ \\
\hline
\end{tabular}

Table 6. Wilks' Lambda for the interaction P-values of Magnesium Oxide Dentin Matrix Protein -1 (DMP-1) Expression at Different Time Intervals $(P<0.001)$

\begin{tabular}{|l|l|l|l|l|l|}
\hline Test & Value & Approx. F & Num DF & Den DF & Prob>F \\
\hline Wilks' Lambda & 0.199263 & 3.8978 & 14 & 44 & $0.001^{*}$ \\
\hline
\end{tabular}

\subsection{Effect of MgO on dentin sialophosphoprotein (DSPP) expression of HDPCs at various concentrations}

Data evaluation showed a significant increase of DSPP expression in the $0.5 \mathrm{~mm}$ supplemental $\mathrm{MgO}$ concentration group $(P<0.001)$ at 7,10 , and 14 days compared to the negative control and vehicle control groups $(p<0.001)$ (Figure 4) (Table 7). Meanwhile, for $\mathrm{MgO}$ concentration groups higher than $0.5 \mathrm{mM}$ DSPP, DSPP expression decreased significantly comparable to the negative control and vehicle control groups $(p<0.001)$. Regarding the lignin sulfonic acid sodium salt and xanthan gum vehicle control groups, there were some differences in their DSPP expression compared to the negative control (Figure 4). Wilks' Lambda interaction P- value for $\mathrm{MgO}$ concentrations and their DSPP expression at these time intervals ( 7 and 10 days) showed a statistically significant value $(p<0.001)$ (Table 8$)$. The comparison of different time intervals for the whole assay could be depicted, clearly showing the effect of the $0.5 \mathrm{mM}$ supplemental $\mathrm{MgO}$ concentration group on DSPP expression of HDPCs. Interestingly, the vehicle control groups lignin sulfonic acid sodium salt and xanthan gum may have a direct stimulating effect on HDPCs as evidenced by various levels of increase in DSPP expression. 


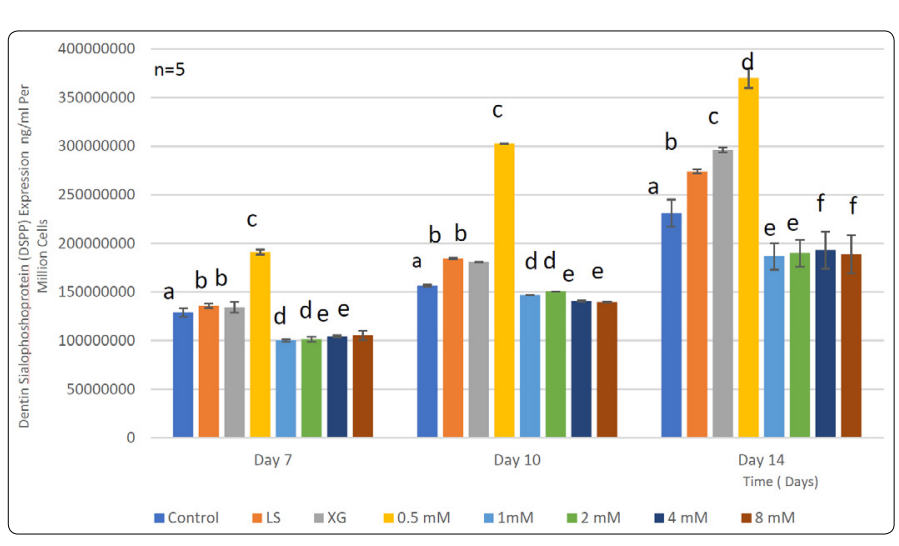

Figure 4. Bar graph showing dentin sialophospho protein (DSPP) expression of normal human pulp cells in media supplemented with magnesium oxide (Mg O) concentrations $0.5 \mathrm{mM}, 1 \mathrm{mM}, 2 \mathrm{mM}, 4 \mathrm{mM}, 8$ $\mathrm{mM}$ and $0 \mathrm{mM}$ as control group, lignin sulfonic acid sodium salt and xanthan gum as vehicle controls for time periods of 7,10, and 14 days. Dentin sialophospho protein (DSPP) expression in supernatants was normalized per million cells at each time interval. The control cells were treated without supplemental magnesium oxide. Different letters indicate a significant difference between groups $(P<0.001)$ compared to the control in each condition at the specified time point. Error bars indicate the standard deviations of five replicates

Table 7. P-values within Groups for Multi-way ANOVA (MANOVA) for Dentin Sialophospho Protein (DSPP) Expression of Magnesium Oxide (MgO) Concentrations $(<0.001)$

\begin{tabular}{|l|l|l|l|l|l|}
\hline Test & Value & Exact F & Num DF & Den DF & Prob $>$ F \\
\hline F Test & 40.060579 & 961.4539 & 1 & 24 & $<.001^{\star}$ \\
\hline
\end{tabular}

Table 8. Wilks' Lambda for the interaction P-values of Magnesium Oxide Dentin Sialophospho Protein (DSPP) Expression at Different Time Intervals $(P<0.001)$

\begin{tabular}{|l|l|l|l|l|l|}
\hline Test & Value & Approx. F & NumDF & DenDF & Prob $>\mathbf{F}$ \\
\hline Wilks' Lambda & 0.0213249 & 19.2145 & 14 & 46 & $<.001^{*}$ \\
\hline
\end{tabular}

\subsection{Effect of MgO on collagen-type I (COL-I) expression of HDPCs at various concentrations}

COL-I expression of HDPCs was analyzed at 7, 10, and 14 days. A significant increase was noted in the $0.5 \mathrm{mM}$ supplemental $\mathrm{MgO}$ concentration group $(P<0.001)$ at all time intervals compared to the negative control and vehicle control groups (Figure 5). In the $0.5 \mathrm{mM} \mathrm{MgO}$ concentration group, there were also significant time-dependent increase of COL-I expression from day 7 to day $14(P<0.001)$. (Figure 5) (Table 9). Wilks' Lambda interaction $\mathrm{P}$ - value for $\mathrm{MgO}$ concentrations and their collagen alpha-1 (I) chain expression presented a statistically significant value $(p<0.001)$ (Table 10$)$. For other $\mathrm{MgO}$ concentration groups higher than $0.5 \mathrm{mM}$, results of COL-I expression were comparable to the negative control with a statistically significant difference $(P<0.001)$. Wilks' Lambda interaction P-value for supplemental $\mathrm{MgO}$ concentrations and their COL-I expression demonstrated a statistically significant value $(p<0.001)$. A noticeable effect was denoted by the $0.5 \mathrm{mM}$ supplemental on $\mathrm{MgO}$ concentration group causing an enhanced effect on COL-I expression. The vehicle control groups ligninsulfonic acid sodium salt and xanthan gum may have an enhancing effect on HDPCs as noticed by increase in COL-I expression.

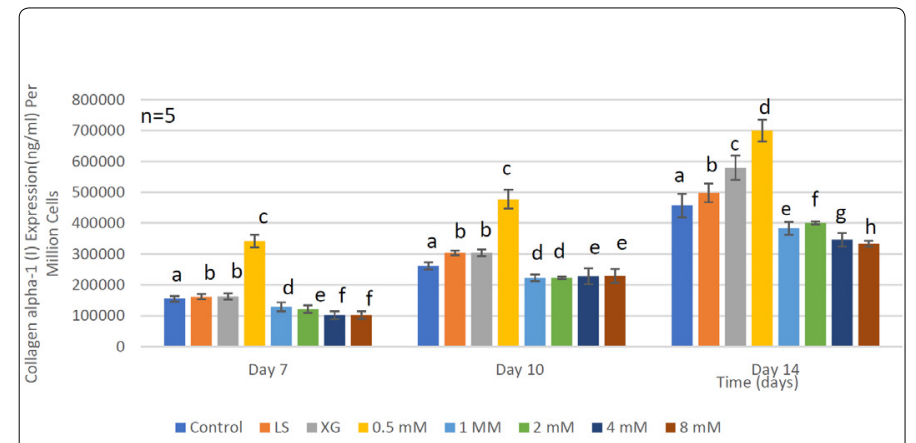

Figure 5. Bar graph showing Type I collagen (COL-I) expression of normal human pulp cells in media supplemented with magnesium oxide $(\mathrm{Mg} \mathrm{O})$ concentrations $0.5 \mathrm{mM}, 1 \mathrm{mM}, 2 \mathrm{mM}, 4 \mathrm{mM}, 8 \mathrm{mM}$ and $0 \mathrm{mM}$ as control group, lignin sulfonic acid sodium salt and xanthan gum as vehicle controls for time periods of 7,10, and 14 days. Type I collagen (COL-I) expression in supernatants was normalized per million cells at each time interval. The control cells were treated without supplemental magnesium oxide. Error bars indicate the standard deviations of five replicates

Table 9. P-values within Groups for Multi-way ANOVA (MANOVA) for Collagen-Type I (COLI) Expression of Magnesium Oxide (MgO) Concentrations $(<0.001)$

\begin{tabular}{|l|l|l|l|l|l|}
\hline Test & Value & Exact F & Num DF & Den DF & Prob $>$ F \\
\hline F Test & 0.3200202 & 7.6805 & 1 & 24 & $<0.001^{\star}$ \\
\hline
\end{tabular}

Table 10. Wilks' Lambda for the interaction P-values of Magnesium Oxide Collagen -Type I (COLI) Expression at Different Time Intervals $(P<0.001)$

\begin{tabular}{|l|l|l|l|l|l|}
\hline Test & Value & Approx. F & Num DF & Den DF & Prob $>$ F \\
\hline Wilks' Lambda & 0.3973566 & 1.9267 & 14 & 46 & $<0.001^{*}$ \\
\hline
\end{tabular}

\section{Discussion}

Regenerative endodontic therapy involves biological procedures for replacing damaged dental structures such as dentin, and cells of the dentin/pulp complex [31]. Human dental pulp stem cells (hDPSCs) can proliferate and differentiate into odontoblasts and subsequently deposit reparative dentin as a stress reaction when the pulp tissue is subjected to certain stimulation [32]. When exposed pulp is capped by biocompatible materials, hDPSCs migrate to the injured site, proliferate, and differentiate into odontoblastlike cells, which subsequently deposit reparative dentin $[33,34]$. Meanwhile, the identification and development of appropriate biomaterials are necessary to optimize clinical approaches to dentinogenesis. Therapeutic ions might have roles as cofactors in cellular metabolism, signaling pathways, ionic channels, and other biologic procedures [35]. Therapeutic ions might induce cellular signaling, triggering resident pulp cells to differentiate in to odontoblast-like cells, stimulation of dentin matrix secretion, and formation of tertiary dentin [36]. It has been shown in the literature that therapeutic ions such as lithium, magnesium, strontium and zinc enhance osteogenic differentiation of mesenchymal stem cells, and regulate osteoblast mediated bone formation [37]. In this study, it was hypothesized that $\mathrm{MgO}$ can trigger the odontoblastic differentiation of HDPCs, in terms of the 
expression of dentin sialoprotein (DSP), dentin matrix protein (DMP-1), dentin sialophosphoprotein (DSPP) and Type I collagen (COL-I), leading to a better understanding of the molecular and cellular bases for pulp regeneration and dental tissue repair in an effort to develop biologically based strategies for successful endodontic treatment.

Studies revealed the favorable behavior and the improved biological outcomes of MgO-modified silicate glasses, where $\mathrm{MgO}$ was preferred to other oxides on account of their documented benefits to bone regeneration $[38,39]$ studied the stimulatory effects of $\mathrm{MgO}$ on early bone cell differentiation, reported that osteoblasts cultured on bioactive $\mathrm{SiO}_{2}-\mathrm{CaO}-\mathrm{P}_{2} \mathrm{O}_{5}-\mathrm{MgO}$ glass exhibited high ALP activity. Similarly, [40] demonstrated that $\mathrm{MgO}$ enhanced the temporal expression of bone related genes and proteins (type I collagen $(\mathrm{Col} \mathrm{I})$, osteocalcin $(\mathrm{OC})$, osteopontin (OP), osteonectin (ON), alkaline phosphatase (ALP) and bone sialoprotein (BSP) by bioactive $\mathrm{MgO}$-glass ceramic in human bone-derived cells (HBDC). Therefore, chemistry modification with $\mathrm{MgO}$ had the utmost effect on osteoblastic differentiation promoting optimal osteogenesis [41]. Studied MC3T3-E1 osteoblast like cells cultured on composite scaffolds consisting of poly (I-lactide) matrix and grafted $\mathrm{MgO}(\mathrm{gMgO})$ whiskers, showing a significant increase in ALP expression and calcium deposition nodules [42]. Reported that poly(lactide-co-glycolide) (PLGA) co-embedded with $1 \mathrm{wt} \% \mathrm{MgO}$ upregulated osteogenic differentiation and high ALP activity levels of bone marrow mesenchymal stromal cells (BMMSCs) [43]. Studied osteogenic differentiation of MC3T3-E1 cells cultured on magnesium hydroxyapatite whiskers/poly (D, L-lactide) (Mg- HAp-Ws/ PDLLA), led to an up-regulation of ALP expression in MC3T3-E1 cells. From the above forementioned studies, it is evident that $\mathrm{MgO}$ has an influence on cell differentiation and bone formation of osteoblasts by stimulating expression of growth factors and osteogenic proteins.

In the present study, normal human pulp cells were isolated from the pulp tissue of extracted teeth and were able to differentiate and produce extracellular matrix (ECM) proteins, which are the substrate for mineralization during dentin formation. To induce differentiation of isolated HPDCs, differentiation medium containing ascorbic acid, vitamin D3 and dexamethasone was used. It was noticed that the proliferation and viability of HDPCs first increased and then gradually stopped, starting from day 14 of culture [26], when the cells began to differentiate. The differentiation from dental pulp cells into odontoblasts was evaluated for the expression of extracellular dentin matrix proteins associated with odontoblastic differentiation, such as DSP, DMP-1, DSPP, and COLI.

During dentinogenesis the expression of extracellular matrix (ECM) proteins by preodontoblasts changes concomitantly with the stage of differentiation. Of these ECM proteins, some are present throughout all stages of dentinogenesis, while others can only be demonstrated at particular stages of differentiation. Dentin sialoprotein (DSP) is one of the crucial factors to determine odontoblast differentiation. Previous studies have suggested that DSP plays a role in regulating the initiation of dentin mineralization. It was reported that the expression of DSP is present in the early stages of odontoblast differentiation, increased in mature odontoblasts and decreased when pulp cells differentiate showing temporal and spatial expression patterns within the developing and mineralizing dentin [44]. DSP is synthesized by odontoblasts and secreted at the mineralization front via odontoblastic processes, which suggests a unique role for DSP in the conversion of uncalcified predentin to calcified dentin $[45,46]$. Moreover, DSP functioning as an intracellular transducer is able to induce tooth related protein expression through signaling pathways. DSP binds to cell membrane proteins as a result of intracellular protein kinases regulating intracellular activity via focal adhesion kinase (Fak) which is a non-receptor bound tyrosine kinase involved in mediating both integrin and occludin (Ocln) signaling for regulating intracellular transduction with the ECM $[44,47]$. Previous studies have also suggested that DSP plays a role in regulating the initiation of dentin mineralization. These findings on the importance of DSP in dentin formation are further supported by similar studies that identified 36 amino acids of DSP domain bind to integrin $\beta 6$ and the DSP-integrin $\beta 6$ complex to stimulate phosphorylation of SMAD1/5/8 proteins [48]. Comparing DSP expression at different time intervals throughout the present study clearly demonstrated the direct stimulating effect of DSP expression with $0.5 \mathrm{mM} \mathrm{MgO}$ concentration group on HDPCs. The data of the present study revealed that at 7 days optimal $\mathrm{MgO}$ concentration group showed an increase in the DSP expression. Moreover, at days 10, and 14 the same concentration group had a significantly higher increase in DSP expression. These results are in agreement with [49] that DPSCs cultured in $\mathrm{Mg}^{2+}$-enriched odontogenic medium showed markedly elevated DSP protein amounts with the same trend regarding the concentration range and the time points. Therefore, these findings confirm that both normal HDPCs and DPSCs cells could exhibit similarities in DSP expression.

Extracellular DMP-1 plays essential roles as a physiological regulator of osteoblast/odontoblast-specific genes/protein in osteogenesis and odontogenesis [50-52]. The primary localization of DMP-1 is in the nucleus [53]. $\mathrm{Ca}^{2+}$ was responsible for the export of DMP-1 into the extracellular matrix during osteoblast differentiation. DMP-1 plays a role in dentinogenesis, in addition to its signaling properties. In vitro, DMP-1 is involved in the regulation of biomineralization probably due to its calcium binding capacity [54]. Confirmed great affinity of DMP-1 to collagen fibrils that might regulate growth of calcium-phosphate crystals. These investigators proposed that during the maturation of the pre-odontoblast/ odontoblast, nuclear DMP-1 would be phosphorylated by casein kinase II, leading to its exportation into the extracellular matrix where it promotes hydroxyapatite formation. Several studies postulated that DMP-1 may be used as an effective stimulator for dental pulp stem/progenitor cell differentiation targeting undifferentiated cells at the repair site $[55,56]$. In the 
present study, assessment of DMP-1 expression of HDPCs was significantly up-regulated during the entire experiment with $0.5 \mathrm{mM}$ supplemented $\mathrm{MgO}$, compared to the control groups. These results are in accordance with [57] who studied the effect of bioactive glass containing $1 \% \mathrm{wt} / \mathrm{wt} \mathrm{MgO}$ and reported the upregulation of DMP-1 expression level on human dental pulp stem cells (hDPSCs). Moreover, the results of the present in vitro study confirm with [49], [58,59] whom stated that low extracellular $\mathrm{Mg}^{2+}$ enriched microenvironment regulated osteogenic and odontogenic differentiation in both human DPSCs, and bone marrow mesenchymal stem cells (BMSCs) respectively.

DSPP is a positive regulator for mineralization of highly organized intrafibrillar collagen [60]. DSPP is produced by terminally differentiated odontoblasts and is known to modulate dentin mineralization and tooth development [61]. Mutations of DSPP cause dentinogenesis imperfecta type II, type III, and dentin dysplasia type II [62,63]. DSPP and DMP-1 null mice (11) display a very similar defect in later stages of dentinogenesis, suggesting a strong connection between these two proteins. DSPP was reduced in DMP-1null mice at both the mRNA and protein levels [64]. This finding is in agreement with an in vitro study by [53], in which over expression of DMP-1 induced DSPP expression. These authors reported that DSPP is probably one of the targeted molecules by DMP-1, and changes in DSPP may explain, in part, some of the defects observed in DMP-1 null mice. Previous studies demonstrated that DSPP expression in preodontoblasts and during odontoblast lineage coincides with BMP2 expression, which is first expressed in early bell stage mesenchymal cells $[65,66]$. Previous studies also demonstrated that exogenous addition of DSPP is effective for undifferentiated mesenchymal cells and osteoblastic cells to differentiate into mature osteoblasts and/or odontoblasts through the recombinant DSPP binding to cell membrane integrin via its RGD binding site, triggering intracellular signals for expression of bone/ dentin differentiation proteins $[67,68]$. The differential regulation of these signaling pathways suggests the regulatory role played by DSPP directly or indirectly regulating transcription/growth factors, matrix molecules, to orchestrate the process of dentin formation, directing mesenchymal cell commitment towards the odontoblast differentiation and maturation process. DSPP expression at different time points throughout the present study clearly demonstrated the direct enhancing effect with $0.5 \mathrm{mM}$ supplemental $\mathrm{MgO}$ on HDPCs. These results are in accordance with $[69,70]$ whom similarly showed an upregulatory effect by incorporating low extracellular $\mathrm{Mg}^{2+}$ ion concentration into calcium phosphate cement (CPC) which promoted the proliferation and differentiation of human bone marrow stem cells. Despite the fact of using human bone marrow stem cells and human pulp cells, both cell types showed a similar biochemical response to optimal $\mathrm{Mg}^{2+}$ supplement concentration. Incorporated $\mathrm{Mg} 2+$ into nanofibrous gelatin (NF-gelatin) matrices to form a hybrid scaffold for enhanced dentin regeneration [13]. DSPP expression was significantly higher in the NF-gelatin/ $\mathrm{Mg}$ scaffold than in the NF-gelatin scaffold (control).
Treatment with low $\mathrm{Mg}^{2+}$ ion concentration benefitted DPSC differentiation. Moreover, Ahn et al. [57] reported an increase in DSPP expression level of hDPSCs cultured on bioactive glass containing $1 \mathrm{MgO} \mathrm{wt} / \mathrm{wt} \%$ at 7 days. The composites showed a significantly higher increase in DSPP expression at both 10 and 14 days. These findings confirm with the results of the present study denoting a similar trend at the same concentration and the same time points although in different cell types.

Type I collagen is a major organic component of dentin and has been shown to influence functions of osteoblasts [71]. These effects are mediated by the interaction of collagen with integrin receptors on cell membrane, and the interruption of collagen-integrin abolished the effect of collagen on cells [72]. Several studies have used materials that mimic aspects of the architecture of natural dental ECM for the regeneration of damaged dentin/pulp tissues. Gelatin/bioactive glass hybrid scaffolds provided an excellent environment for the odontogenic differentiation of DPSCs [73]. Collagen I scaffold accelerated odontogenic differentiation and mineralization of stem cells from exfoliated deciduous teeth [74]. Developed an ECM scaffold composed of collagen I/chitosan that was able to induce odontogenic differentiation of DPSCs, and to form dental pulp-like tissue when implanted subcutaneously in mice [75]. Demonstrated that the DPSCs/NF-gelatin/MgP construct produced greater ECM deposition, hard tissue formation, and expression of Col I protein in nude mice. Specifically, the expression of Col I on the hybrid scaffold group was more than fourfold higher than on the control group $[13,76]$ clarified the biological behavior effect of $10 \mathrm{mM}$ $\mathrm{Mg}^{2+} / \mathrm{Col}$. I coating which promoted proliferation, differentiation, and expression of osteogenic proteins (Runx2, ALP and OCN, OPN and BMP-2) in MC3T3-E1 cells. To reveal the effect of surface chemistry modification of bioceramics by $\mathrm{Mg}^{2+}$ ions on protein expression (collagen type I, $\alpha 5$-, $\beta 1$-integrin), [77] reported significantly increased bone cell adhesion on magnesium-enriched alumina. Cells grown on magnesium substrates expressed a significantly enhanced level of $\alpha_{5} \beta_{1}$ integrin receptor, in addition to increased expression of collagen I extracellular matrix protein. Reported the effect of low $\mathrm{MgO}$ concentration on the upregulated expression of COL I on human bone derived cells (HDBC) cultured on glass ceramics $[40,78]$. Similarly, Banerjee et al. [79], demonstrated that-TCP implants doped with 1.0 wt.\% MgO, cultured on human fetal osteoblast cells (hFOB), enhanced osteogenic differentiation and expression of COL-I. In the present study, data revealed that the $0.5 \mathrm{mM} \mathrm{MgO}$ concentration group presented a statistically significant increase in the expression of COL-I of human dental pulp cells compared to the negative control at day 7. COL-I at days 10 and 14 showed a significantly higher expression among the same group of $0.5 \mathrm{mM} \mathrm{MgO}$. This is the first report on normal human dental pulp cells compared to other studies on stem cells and animal cell lines. The results of the present work are consistent with the above listed studies that the incorporation of $\mathrm{Mg}^{2+}$ ions significantly enhanced the differentiation and $\mathrm{COL} I$ expression of human DPSCs, human bone derived cells (HDBC), human fetal 
osteoblast cells, and MC3T3-E1 cells $[40,76,78,79]$. In the present study, $\mathrm{MgO}$ concentrations at or higher than $0.5 \mathrm{mM}$ showed a significant inhibitory effect on expression of extracellular matrix proteins. This phenomenon also has been validated by various in vitro studies $[80,81] . \mathrm{Mg}^{2+}$ is considered to be a physiological antagonist of $\mathrm{Ca}^{2+}$ and can compete with $\mathrm{Ca}^{2+}$ for protein and transporter binding. With a high level of extracellular $\mathrm{Mg}^{2+}, \mathrm{Mg}^{2+}$ ions penetrate into the cells more quickly. It was proposed that at the same time, to maintain ion homeostasis in the body, intracellular $\mathrm{Mg}^{2+}$ ions have negative feedback inhibition on the TRPM7 channel, thus closing the channel activity and shielding the penetration of other ions [82]. Meanwhile, $\mathrm{Mg}^{2+}$ ion is important in controlling cell cycle progression, especially during the initiation of DNA synthesis and during mitosis [83]. With higher $\mathrm{Mg}^{2+}$ levels, $\mathrm{Mg}^{2+}$ ions may locally distort the double helix due to covalent bonding with DNA. Therefore, changes in the availability of $\mathrm{Mg}^{2+}$ ions in cells may cause blocked signaling and in turn affect the proliferation and differentiation. The findings of the above-forementioned studies confirm with the present data demonstrating the role of low optimal $\mathrm{MgO}$ concentration in collagen expression.

\section{Conclusion}

In the present study, $0.5 \mathrm{mM} \mathrm{MgO}$ supplements enhanced odontogenic differentiation in HDPCs as evidenced by upregulated expression of extracellular proteins, DSP, DMP-1, DSPP, and collagen type I. The data in this study demonstrated for the first time the role of optimal supplemental $\mathrm{MgO}$ concentration in dentinogenesis of HDPCs.

\section{Conflict of Interests}

The authors declare no conflict of interests.

\section{Funding Statement}

The authors declare no financial support

\section{Data Availability Statement}

The raw data used to support the findings of this study are stored at the X220 Research Lab according to Boston University policy. The authors confirm the availability of the raw data used in this manuscript upon request.

\section{References}

1. Bjørndal L, Simon S, Tomson PL, Dunca HF. Management of deep caries and the exposed pulp. Int Endod J. 2019; 52(7): 949-973. doi: 10.1111/ iej.13128

2. Duncan HF, Galler KM, Tomson PL, et al. European Society of Endodontology position statement: Management of deep caries and the exposed pulp. Int Endod J. 2019; 52(7): 923-934. doi: 10.1111/ iej.13080

3. Cushley S, Duncan HF, Lappin MJ, et al. Efficacy of direct pulp capping for management of cariously exposed pulps in permanent teeth: a systematic review and meta-analysis. Int Endod J. 2021; 54(4): 556-571. doi: 10.1111/iej.13449
4. Hilton TJ, Ferracane JL, Mancl L. For Northwest Practice-based Research Collaborative in Evidence-based Dentistry (NWP), Comparison of $\mathrm{Ca}$ $(\mathrm{OH})_{2}$ with MTA for direct pulp capping: a PBRN randomized clinical trial. J Dent Res. 2013; 92(7): 16S-22S. doi: 10.1177/0022034513484336

5. $M$, Roberto $H$, Alessandra R, Murata SS, et al. Evaluation of mineral trioxide aggregate and calcium hydroxide cement as pulp-capping agents in human teeth. J Endod. 2008; 34(1): 1-6. doi: 10.1016/j. joen.2007.09.012

6. Johannes $M$, Hufnagel $S$, Meltem $L$, et al. Treatment outcome of mineral trioxide aggregate or calcium hydroxide direct pulp capping: long-term results. J Endod. 2014; 40(11): 1746-51. doi: 10.1016/j.joen.2014.07.019

7. Ishimoto K, Hayano S, Yanagita $T$, et al. Topical application of lithium chloride on the pulp induces dentin regeneration. PLoS One. 2015; 10(3): 1-13e0121938. doi: 10.1371/journal.pone.0121938

8. Pratia C, Gandolfi MG. Calcium silicate bioactive cements: Biological perspectives and clinical applications. Dent Mater. 2015; 31(4): 351-70. doi: 10.1016/j.dental.2015.01.004

9. Zhang J, Zhu LX, Cheng X, et al. Promotion of Dental Pulp Cell Migration and Pulp Repair by a Bioceramic Putty Involving FGFR-mediated Signaling Pathways. J Dent Res. 2015; 94(6): 853-62. doi: $10.1177 / 0022034515572020$

10. Xuan K, Li B, Guo H, et al. Deciduous autologous tooth stem cells regenerate dental pulp after implantation into injured teeth. Sci Transal Med. 2018; 10(455): 1-15. doi: 10.1126/scitransImed.aaf3227

11. Ravindran S, Huang CC, George A. Extracellular matrix of dental pulp stem cells: applications in pulp tissue engineering using somatic MSCs. Front Physiol. 2014; 4(395): 1-11. doi: 10.3389/fphys.2013.00395

12. Yang JW, Zhang YF, Sun ZY, Song GT, Chen Z. Dental pulp tissue engineering with bFGF-incorporated silk fibroin scaffolds. J Biomater Appl. 2015; 30(2): 221-9. doi: 10.1177/0885328215577296

13. Qu T, Jing J, Jiang $Y$, et al. Magnesium-containing nanostructured hybrid scaffolds for enhanced dentin regeneration. Tissue Eng A. 2014; 20(1718): 2422-2433. doi: 10.1089/ten.TEA.2013.0741

14. Li FY, Chaigne-Delalande B, Kanellopoulou C, et al. Second messenger role for $\mathrm{Mg}^{2+}$ revealed by human T-cell immunodeficiency. Nature. 2011; 475(7357): 471-76. doi: 10.1038/nature10246

15. Maguire ME, Cowan JA. Magnesium chemistry and biochemistry. Biometals. 2002; 15(3): 203-10. doi: 10.1023/a:1016058229972

16. Wolf Fl, Cittadini A. Chemistry and biochemistry of magnesium. Mol Asp Med. 2003; 24(1-3): 3-9. doi: 10.1016/s0098-2997(02)00087-0

17. Wiesmann $H P$, Tkotz $T$, Joos $U$, et al. Magnesium in newly formed dentin mineral of rat incisor. J Bone Miner Res. 1997; 12(3): 380-3. doi: 10.1359/ jbmr.1997.12.3.380

18. Albulescu R, Popa AC, Enciu AM, et al. Comprehensive In Vitro Testing of Calcium phosphate- based bioceramics with orthoedic and dentistry applications. Materials. 2019; 12(3704): 1-41. doi: 10.3390/ma12223704

19. Ma FQ, Lu XL, Wang ZM, Sun ZJ, Zhang FF, Zheng YF. Nanocomposites of poly(L-lactide) and surface modified magnesia: Fabrication, mechanical property and biodegradability. J Phys Chem. Solids. 2011 72(2): 111-11. doi: 10.1016/j.jpcs.2010.11.008

20. Gao $C$, Peng $S$, Feng $P$, Shuai $C$. Bone biomaterials and interactions with stem cells. Bone Research. 2017; 5(17059): 1-33. doi: 10.1038/ boneres.2017.59

21. Yuan Z, Wei P, Huang Y, et al. 2cta Biomaterialia. 2019; 2(85): 294-309.

22. Sergi R, Bellucci D, Cannillo VA. Review of Bioactive Glass/Natural Polymer Composites: State of the Art. Materials. 2020; 13 (5560): 1-38. doi: $10.3390 / \mathrm{ma} 13235560$

23. Zhao $\mathrm{Y}$, Liang $\mathrm{H}$, Chen $\mathrm{M}$. Effects of Magnesium Oxide (MgO) Shapes on In Vitro and In Vivo Degradation Behaviors of PLA/MgO Composites in Long Term. Polymers (Basel). 2020; 12(15): 1-13. doi: 10.3390/polym12051074

24. Bose $S$, Roy $M$, Bandyopadhyay $A$. Recent advances in bone tissue engineering scaffold. Trends Biotechnol. 2012; 30(10): 546-554. doi: 10.1016/j.tibtech.2012.07.005 
25. Diba M, Tapia F, Boccaccini AR, Strobel LA. Magnesium-Containing Bioactive Glasses for Biomedical Applications. Special Issue. Progress in Glass Science and Engineering. 2012; 3(3): 221-253. doi: 10.1111/j.2041-1294.2012.00095.x

26. Salem R, Zhang C, Chou L. Dentinogenic Effect of Magnesium oxide on human dental pulp cells: an in vitro study. Madridge J Dent Oral Surg. 2021; 6(1): 106-115. doi: 10.18689/mjdl-1000124

27. Nakashima M, lohara K, Sugiyama M. Human dental pulp stem cells with highly angiogenic and neurogenic potential for possible use in pulp regeneration. Cytokine Growth Factor Rev. 2009; 20(5): 435-440. doi: 10.1016/j.cytogfr.2009.10.012

28. Tatullo $M$, Marrelli $M$, Shakesheff KM, White LJ. Dental pulp stem cells: function, isolation and applications in regenerative medicine. J Tissue Eng Regen Med. 2015; 9(11): 1205-1216. doi: 10.1002/term.1899

29. Richard H. Van de Walle. Concentrated suspension of aqueous magnesium oxide. Patent number: 4834957, Filed: April 21, 1987, Date of Patent: May 30, 1989, Assignee: Martin Marietta Corporation

30. Raoof M, Yaghoobi MM, Derakhshani A, et al. A modified efficient method for dental pulp stem cell isolation. Dent Res J (Isfahan). 2014; 11(2): 244-50.

31. Metlerska J, Fagogeni I, Nowicka A. Efficacy of autologous platelet concentrates in regenerative endodontic treatment: a systematic review of human studies. J Endod. 2019; 45(1): 20-30 e21. doi: 10.1016/j. joen.2018.09.003

32. Yu F, Dong Y, Yang YW, et al. Effect of an experimental direct pulpcapping material on the properties and osteogenic differentiation of human dental pulp stem cells. Sci Rep. 2016; 6(1): 1-11. doi: 10.1038/ srep34713

33. Gronthos S, Mankani M, Brahim J, Robey PG, Shi S. Postnatal human dental pulp stem cells (DPSCs) in vitro and in vivo. Proc Natl Acad Sci USA. 2000; 97(25): 625-630. doi: 10.1073/pnas.240309797

34. Olsson $\mathrm{H}$, Petersson $\mathrm{K}$, Rohlin M. Formation of a hard tissue barrier after pulp cappings in humans. A systematic review. Int Endod J. 2006; 39(6): 429-442. doi: 10.1111/j.1365-2591.2006.01116.x

35. Glenske K, Donkiewicz P, Barbeck M. Applications of Metals for Bone RegenerationInt. J Mol Sci. 2018; 19(3): 836 1-32.

36. Chen FM, Liu X. Advancing biomaterials of human origin for tissue engineering. Prog Polym Sci. 2016; 1(53): 86-168. doi: 10.1016/j. progpolymsci.2015.02.004

37. RuéEB, Tercero LD, Kelhoffer BG, et al. Biological Roles and Delivery Strategies for lons to Promote Osteogenic Induction. Front Cell Dev Biology. 2020; 8(1): 614545; 1-19. doi: 10.3389/fcell.2020.614545

38. Wang W, Yeun $\mathrm{G} \mathrm{KW}$. Bone grafts and biomaterials substitutes for bone defect repair: A review. Bioactive Materials. 2017; 2(4): 224-247. doi: 10.1016/j.bioactmat.2017.05.007

39. Saboori A, Rabiee M, MoztarzadehF, Sheikhi M. Synthesis, characterization, and in vitro bioactivity of sol-gel-derived $\mathrm{SiO} 2-\mathrm{CaO}-$ P2O5-MgO bioglass. Materials Science and Engineering C. 2009; 29(1): 335-340. doi: 10.1016/j.msec.2008.07.004

40. Knabe $C$, Stiller $M$, Berger $G$, et al. The effect of bioactive glass ceramics on the expression of bone-related genes and proteins in vitro. Clin Oral Implants Res. 2005; 16(1): 119-27. doi: 10.1111/j.1600-0501.2004.01066.x

41. Liu K, Li W, Chen S, Wen W, Mingxian L. The design, fabrication and evaluation of 3D printed gHNTs/gMgO whiskers/PLLA composite scaffold with honeycomb microstructure for bone tissue engineering. Composites Part B: Engineerig. 2020; 192(10): 108-118. doi: 10.1016/j. compositesb.2020.108001

42. Yuan Z, Wei $P$, Huang $Y$, et al. Injectable PLGA microspheres with tunable magnesium ion release for promoting bone regeneration. Acta Biomaterialia. 2019; (85): 294-309. doi: 10.1016/j.actbio.2018.12.017

43. Li W, Lu Y, Liu K, et al. Preparation of HAp whiskers with or without Mg ions and their effects on the mechanical properties and osteogenic activity of poly(d,l-lactide) Composites Part B: Engineerig. 2020; 196(1): 1-13. doi: 10.1016/j.compositesb.2020.108137
44. Li W, Chen L, Chen $Z$, et al. Dentin sialoprotein facilitates dental mesenchymal cell differentiation and dentin formation. Sci Rep. 2017; 7(300): 1-18. doi: 10.1038/s41598-017-00339-w

45. Ritchie $H$. The functional significance of dentin sialoproteinphosphophoryn and dentin sialoprotein. Int J Oral Sci. 2011; 10(4): 31-6. doi: 10.1038/s41368-018-0035-9

46. Butler WT, Brunn JC, Qin C, McKee M. Extracellular Matrix Proteins and the Dynamics of Dentin Formation. Connect Tissue Res. 2002; 43(2): 3017. doi: $10.1080 / 03008200290000682$

47. Schlaepfer DD, Jones KC, Hunter T. Multiple Grb2-mediated integrinstimulated signaling pathways to ERK2/mitogen-activated protein kinase: summation of both c-Src- and focal adhesion kinase-initiated tyrosine phosphorylation events. Mol Cell Biol. 1998; 18(5): 2571-85. doi: 10.1128/MCB.18.5.2571

48. Xiao-hui G, Ji-hua C, Guo-hua Y. DSpaa183-219 Regulates Activity of Smad Protein by Interacting with Integrin $\beta 6$. J Oral Sci Res. 2019; 35(6): 537540. doi: 10.13701/j.cnki.kqyxyj.2019.06.007

49. Kong $Y$, Hu X, Zhong $Y, X u K$, Wu B, Zheng J. Magnesium-enriched microenvironment promotes odontogenic differentiation in human dental pulp stem cells by activating ERK/BMP2/Smads signaling. Stem Cell Res Ther. 2019; 10(1): 378. doi: 10.1186/s13287-019-1493-5

50. Wu $\mathrm{H}$, Teng PN, Sfeir $\mathrm{C}$, et al. Dentin Matrix Protein 1 (DMP1) Signals via Cell Surface Integrin. J Biol Chem. 2011; 286(34): 29462-29469. doi 10.1074/jbc.M110.194746

51. Qin C, D'Souza R Feng JQ. Dentin matrix protein 1 (DMP1): new and important roles for biomineralization and phosphate homeostasis. $J$ Dent Res. 2007; 86(12): 1134-41. doi: 10.1177/154405910708601202

52. Sun $Y$, Chen L, Ma S, et al. Roles of DMP1 Processing in Osteogenesis, Dentinogenesis and Chondrogenesis. Cells Tissues Organs. 2011; 194(24): 199-204. dol: 10.1159/000324672

53. Narayanan K, Gajjeraman S, Ramachandran A, Hao J, George A. Dentin Matrix Protein 1 Regulates Dentin Sialophosphoprotein Gene Transcription. J Biol Chem. 2006; 281(28): 19064-19071. doi: 10.1074/jbc. M600714200

54. Gajjeraman S, Narayanan K, Hao J, Qin C, George A. Matrix Macromolecules in Hard Tissues Control the Nucleation and Hierarchical Assembly of Hydroxyapatite. J Biol Chem. 2007; 282(2): 1193-204. doi: 10.1074/jbc.M604732200

55. He G, George A. Dentin Matrix Protein 1 Immobilized on Type I Collagen Fibrils Facilitates Apatite Deposition in vitro. J Biol Chem. 2004; 279(12): 11649-11656. doi: 10.1074/jbc.M309296200

56. Prescott RS, Alsanea R, Fayad IM, et al. In vivo generation of dental pulplike tissue by using dental pulp stem cells, a collagen scaffold, and dentin matrix protein 1 after subcutaneous transplantation in mice. $J$ Endod. 2008; 34(4): 421-6. doi: 10.1016/j.joen.2008.02.005

57. Ahn JH, Kim IR, Kim Y, et al. The Effect of Mesoporous Bioactive Glass / Magnesium Oxide Composites on the Differentiation and Mineralization of Human Dental Pulp Stem Cells. Nanomaterials. 2020; 10(620): 1-18. doi: $10.3390 /$ nano10040620

58. Zheng JM, Kong YY, Li YY, Zhang W. MagT1 regulated the odontogenic differentiation of BMMSCs induced by TGC-CM via ERK signaling pathway. Stem Cell Res Ther. 2019; 10(1): 48-56. doi: 10.1186/s13287019-1148-6

59. Cui L, Xu SM, Ma DD, Wu BL. The effect of TRPM7 suppression on the proliferation, migration and osteogenic differentiation of human dental pulp stem cells. Int Endod J. 2014; 47(6): 583-593. doi: 10.1111/iej.12193

60. Lim D, Wu KC, Lee A, Saunders TL, Ritchie HH. DSPP dosage affects tooth development and dentin mineralization. PLOS ONE. 2021; 46(4): 1-12. doi: 10.1371/journal.pone.0250429

61. Suzuki S, Sreenath T, Haruyama N, Honeycutt C, Terse A. Dentin sialoprotein and dentin phosphoprotein have distinct roles in dentin mineralization. Matrix Biol. 2009; 28(4): 221-229. doi: 10.1016/j. matbio.2009.03.006 
62. Molla MD, Fournier BP, Berdal A. Isolated dentinogenesis imperfecta and dentin dysplasia: revision of the classification. Eur J Hum Genet. 2015; 23(1): 445-451. doi: 10.1038/ejhg.2014.159

63. Lee SK, Lee KE, Song SJ, et al. A DSPP Mutation Causing Dentinogenesis Imperfecta and Characterization of the Mutational Effect. BioMed Res Int. 2012; 2013: 948181. doi: 10.1155/2013/948181

64. Jani PH, Gibson MP, Liu C, et al. Transgenic Expression of Dspp Partially Rescued the Long Bone Defects of Dmp1-null Mice. Matrix Biol. 2016; 52-54: 95-112. doi: 10.1016/j.matbio.2015.12.001

65. Chen S, Gluhak-Heinrich J, Martinez M, et al. Bone morphogenetic protein 2 mediates dentin sialophosphoprotein expression and odontoblast differentiation via NF-Y signaling. J Biol Chem. 2008; 283(28): 19359-19370. doi: 10.1074/jbc.M709492200

66. Cho YD, Yoon WJ, Woo KM, Baek JH, Park JC, Ryoo HM. The canonical BMP signaling pathway plays a crucial part in stimulation of dentin sialophosphoprotein expression by BMP-2. J Biol Chem. 2010; 285(47): 36369-36376. doi: 10.1074/jbc.M110.103093

67. Jadlowiec J, Koch $H$, Zhang X, Campbell PG, Seyedain M, Sfeir C. Phosphophoryn regulates the gene expression and differentiation of NIH3T3, MC3T3-E1, and human mesenchymal stem cells via the integrin/MAPK signaling pathway. J Biol Chem. 2004; 279(51): 5332353330. doi: 10.1074/jbc.M404934200

68. Yasuda Y, Izumikawa M, Okamoto K, Tsukuba T, Saito T. Dentin phosphophoryn promotes cellular migration of human dental pulp cells. J Endod. 2008; 34(5): 575-578. doi: 10.1016/j.joen.2008.02.018

69. Sun Z, Lin C, Wu K, Wang M. Dual mechanism design to enhance bone formation by overexpressed SDF-1 ADSCs in magnesium doped calcium phosphate scaffolds. Materials \& Design. 2021; 208 (109884): 1-13.

70. Hussain A, Bessho K, Takahashi K, Tabata Y. Magnesium calcium phosphate/ $\beta$-tricalcium phosphate incorporation into gelatin scaffold: an in vitro comparative study. J Tissue Eng Regen Med. 2014; 8(11): 91924. doi: $10.1002 /$ term. 1596

71. Lynch MP, Stein JL, Stein GS, Lian JB. The influence of type I collagen on the development and maintenance of the osteoblast phenotype in primary and passaged rat calvarial osteoblasts: Modification of expression of genes supporting cell growth, adhesion, and extra matrix mineralization. Exp Cell Res. 1995; 216(1): 35-45. doi: 10.1006/ excr.1995.1005

72. Mizuno M, Kuboki Y. Osteoblast-related gene expression of bone marrow cells during the osteoblastic differentiation induced by type I collagen. J Biochem. 2001; 129(1): 133-138. doi: 10.1093/oxfordjournals. jbchem.a002824

73. Takeuchi $Y$, Nakayama K, Matsumoto T. Differentiation and cell surface expression of transforming growth factor-beta receptors are regulated by interaction with matrix collagen in murine osteoblastic cells. J Biol Chem. 1996; 271(1): 3938-3944. doi: 10.1074/jbc.271.7.3938

74. Yang $X$, Han G, Pang $X$, Fan M. Chitosan/collagen scaffold containing bone morphogenetic protein-7 DNA supports dental pulp stem cell differentiation in vitro and in vivo. J Biomed Mater Res Part A. 2020; 108(12): 2519-2526. doi: 10.1002/jbm.a.34064

75. Ravindran S, Zhang Y, Huang CC, George A. Odontogenic induction of dental stem cells by extracellular matrix-inspired three-dimensional scaffold. Tissue Eng Part A. 2014; 20(1): 92-102. doi: 10.1089/ten. TEA.2013.0192

76. Nie $X$, Sun $X$, Wang $C$, Yang J. Effect of magnesium ions/Type I collagen promote the biological behavior of osteoblasts and its mechanism. Regenerative Biomaterials. 2020; 7(1): 53-61. doi: 10.1093/rb/rbz03

77. Zreiqat $\mathrm{H}$, Evans $\mathrm{P}$, Howlett $\mathrm{CR}$. Effect of surface chemical modification of bioceramic on phenotype of human bone-derived cells. J Biomed Mater Res. 1999; 44(4): 389-96. doi: 10.1002/(sici)1097-4636(19990315) 44:4<389::aid-jbm4>3.0.co;2-o

78. Kee $\mathrm{D}$, Tarafder S, Vahabzadeh S'Bose S. Effects of $\mathrm{MgO}, \mathrm{ZnO}$, SrO, and $\mathrm{SiO}_{2}$ in glass phosphate scaffolds on in vitro gene expression and in vivo osteogenesis. Mater Sci Eng C Mater Biol Appl. 2019; 96(1): 10-19.

79. Banerjee SS, Tarafder S, Davies NM, et al. Understanding the influence of $\mathrm{MgO}$ and $\mathrm{SrO}$ binary doping on the mechanical and biological properties of beta-TCP ceramics. Acta Biomater. 2010; 6(10): 4167-74.

80. Zhang J, Ma $X$, Lin $D$, et al. Magnesium modication of a calcium phosphate cement alters bone marrow stromal cell behavior via an integrin-mediated mechanism. Biomaterials. 2015; 53(2): 251-264. doi: 10.1016/j.biomaterials.2015.02.097

81. Yoshizawa S, Brown A, Barchowsky A, et al. Magnesium ion stimulation of bone marrow stromal cells enhances osteogenic activity, stimulating the effect of magnesium alloy degradation. Acta Biomater. 2014; 10(6): 2834-42. doi: 10.1016/j.actbio.2014.02.002

82. Ryazanova LV, Rondon $L$, Zierler $\mathrm{S}$, et al. TRPM7 is essential for $\mathrm{Mg}^{2+}$ homeostasis in mammals. Nat Commun. 2010; 1(109): 1-25. doi: 10.1038/ncomms 1108

83. Lu WC, Pringa $E$, Chou L. Effect of magnesium on the osteogenesis of normal human osteoblasts. Magnes Res. 2017; 30(2): 42-52113. doi: $10.1684 / \mathrm{mrh} .2017 .0422$ 